\title{
Images of Occupation in Dutch Film
}

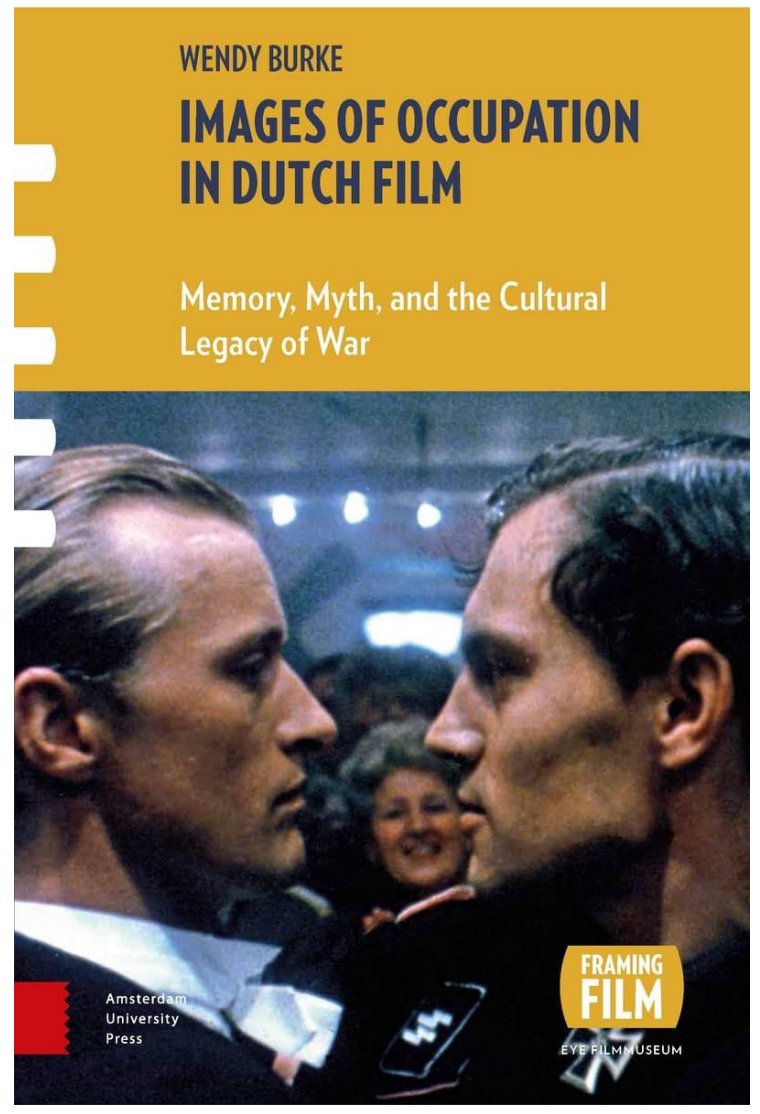

\section{Wendy Burke}

Images of Occupation in Dutch Film. Memory, Myth and the Cultural Legacy of War

Amsterdam University Press, 20I7, 262 pp., ca. $€ 89$,- ISBN 9789089648549 (hardcover) 9789048527090 (e-book)

Het is een van de meest interessante vragen die je als filmhistoricus kunt stellen: kun je een film zien als reflectie van de samenleving? Is het mogelijk de speelfilm op te vatten als een 'barometer van de tijd', als een weerspiegeling van de 'tijdgeest'? De meest uitgesproken opvatting op dit terrein is ooit verwoord door de Duitse filmhistoricus Siegfried Kracauer, die in I947 met zijn From Caligari to Hitler het groeiende nazisme in de Duitse vooroorlogse films probeerde aan te tonen. Wendy Burke treedt met haar onderzoek naar de verbeelding van de bezetting in de Nederlandse speelfilm in de voetsporen van Kracauer: 'The book views film as cultural text - a representation of the past that reveals the concerns of society from the time it was made, whether this happens consciously or not.' (p. II) Films zouden juist door hun collectieve aard - collectief, dat wil zeggen niet gemaakt door een individu - geschikt zijn om als barometer 'unseen dynamics of human relations' (p. 69) bloot te leggen.

Dat idee van reflectie is natuurlijk aantrekkelijk en tot op zekere hoogte te verdedigen. Uiteraard zijn omgangsvormen en modeverschijnselen op het witte doek terug te voeren op de tijd waarin een film is gemaakt. Maar geldt dat ook voor de diepere lagen van de collectieve mentaliteit? En kun je wel spreken over 'de' mentaliteit of 'de' publieke opinie? Of zijn dat optelsommen van soms conflicterende onderstromen? Welke van die onderstromen wordt dan gereflecteerd? En komt dat 'collectief' van een speelfilm niet voort uit een afwijkende subcultuur, zoals in Hollywood of in Hilversum?

Dit soort vragen maakt het begrijpelijk dat de reflectiethese van Kracauer in de loop der jaren stevig onder vuur is genomen en in feite zelden zo wordt toegepast (zie bijvoorbeeld: Chris Vos, Bewegend verleden. Inleiding in de analyse van films en televisieprogramma's (Amsterdam: Boom Onderwijs, 2004), pp. II5-I28). Daarom is het merkwaardig dat Burke in haar theoretische inleiding die kritiek volledig negeert - blijkbaar is ze daar niet van op de hoogte. Ook kent ze de meest invloedrijke opvolger van Kracauer niet: Anton Kaes met zijn studie van de Duitse speelfilm From Hitler to Heimat uit I989. Hij komt in 
haar literatuurlijst en tekst niet voor. Dat is pijnlijk, omdat Kaes niet alleen de methode van Kracauer sterk nuanceert, maar ook hetzelfde onderwerp als Burke behandelt: de representatie van de Tweede Wereldoorlog in de (in dit geval Duitse) speelfilm.

Ook bij de behandeling van het Nederlandse onderzoek op dit terrein valt Burkes eenzijdigheid op. In haar inleiding stelt de auteur dat 'no deeper study deals with representations of occupation in [Dutch] film.' (p. I7) Toch zijn er wel degelijk twee Nederlandse studies in boekvorm over dit onderwerp gepubliceerd. Allereerst In de schaduw van Auschwitz uit 1995 van Frank van Vree, waarin de verbeelding van de oorlog in films en andere culturele uitingen wordt geanalyseerd. Van Vree wordt weliswaar genoemd in de literatuurlijst, maar komt niet terug in de tekst. En ook de in hetzelfde jaar gepubliceerde dissertatie Televisie en bezetting (van deze recensent) over de verbeelding van de bezetting in de Nederlandse televisiedocumentaire, blijft ongenoemd.

Burke heeft acht speelfilms voor haar analyse geselecteerd, waaronder De Overval (1962), Als twee druppels water (1963), Soldaat van Oranje (I977), Pastorale 1943 (1978), De Aanslag (1986) en Zwartboek (2006), hoewel de laatste eigenlijk buiten de onderzochte periode valt. Ze analyseert deze films aan de hand van vier kernthema's, die in evenzovele hoofdstukken worden uitgewerkt. De thema's behelzen het vijandbeeld, de Nederlandse identiteit en 'Dutchness', leven onder de bezetting en collaboratie en verzet.

De analyses zelf voert Burke uit met veel oog voor detail en voor de cinematografische component. Hier is de auteur op haar best: ze weet goed onderbouwd de veranderingen in de door haar bestudeerde kernthema's aan te geven. Interessant is bijvoorbeeld de vergelijking die ze trekt tussen Nederlandse landschap- en portretschilders uit de Gouden Eeuw en de film. Dat het Hollandse licht een rol speelt bij de beide culturele uitingen is haast vanzelfsprekend, maar Burke laat ook zien dat een portretschilder als Vermeer een (wellicht onbewuste) invloed heeft gehad op de framing van een shot in In de schaduw van de overwinning. Ook het onderzoek naar 'Dutchness', de verbeelding van de Nederlandse identiteit, wordt mooi geillustreerd. En het vijandbeeld ondergaat in de loop van de decennia, niet geheel verrassend, een ontwikkeling van zwart-wit naar meer grijstinten.

In verband met haar reflectieopvatting is het leerzaam om eens te kijken naar de weerspiegeling van de grootste verandering die in de jaren zeventig en tachtig plaats vond in de publieke opinie: de Holocaust en de joodse vervolging krijgen een centrale plaats in het beeld van de oorlog. Interessant is dat die verandering niet of nauwelijks in de speelfilms is terug te vinden. Voor Burke wijst dat gemis op een collectief verzwijgen of ontwijken van de schuldvraag (p. I80). En dat zou dan binnen haar kader de mentaliteit in de Nederlandse samenleving moeten weerspiegelen. Dat is echter niet wat andere studies aantonen. Want in vele andere films en documentaires - denk aan de televisieserie Holocaust (I978) of de documentaire Shoah (1985) - zijn die thema's wel degelijk prominent aanwezig. Net zoals in een groot aantal Nederlandse televisiedocumentaires. Die films veroorzaken in Nederland zelfs een dermate sterke verschuiving in het publieke beeld van de oorlog, dat het 'slachtoffer' de plaats inneemt van het 'verzet'.

Juist hier wreekt zich bij de auteur dat kritiekloze vasthouden aan de reflectietheorie van Kracauer. De Nederlandse speelfilm is nooit een simpele reflectie van de 'tijdgeest' of de Nederlandse samenleving geweest. 
Maar wel een actieve participant in het maatschappelijk discours - vaak zelfs een voorloper bij het bepalen van de publieke agenda. De vergelijking met de seksuele revolutie van de jaren zestig en zeventig dringt zich hier op. Ook daar liep de in de film uitgedragen beleving van seksuele vrijheid soms (ver) voor op delen van de samenleving, zeker als je de Randstad vergelijkt met het platteland.

Dit probleem met al dan niet bewuste weerspiegeling speelt bij vrijwel elke film die Burke analyseert. De Overval (I962) beschouwt zij bijvoorbeeld als een haast perfecte reflectie: '(...) how they [de vijand, CV] are portrayed in film in this time conforms to underlying attitudes and prevailing stereotypes about the war in Dutch society.' (p. 75) Maar het nog geen twee jaar later gemaakte Als twee druppels water 'seems out of kilter with certain (though not all) currents of public opinion about the war from the time it was made.' (p. 88) Op basis van welke criteria mag je dan de ene film wél als reflectie betitelen en de andere niet? Het lijkt erop dat de 'text-first' benadering van de auteur hier een hinderpaal is geworden: de productiegeschiedenis en receptie blijven steevast buiten beeld. Terwijl alleen grondig contextonderzoek kan uitwijzen of er werkelijk sprake is van reflectie.

Burkes studie wekt tegenstrijdige gevoelens op. Aan de ene kant is het boek goed geschreven, de analyses van de films zijn interessant en vertonen zowel diepgang als inzicht in de wijze waarop de oorlog wordt gerepresenteerd. Aan de andere kant heeft de auteur studies die direct raken of zelfs overlappen met haar eigen onderzoek niet gelezen en daar dus ook geen lering uit kunnen trekken. Burke heeft de belangrijkste literatuur op dit terrein in binnen- en buitenland gemist - en zeker van de studie van Kaes had ze nog veel kunnen opsteken. Wellicht nog het meest serieuze punt is dat Burke een naïeve opvatting van de reflectietheorie hanteert, die vrijwel al haar bevindingen op losse schroeven zet.

Chris Vos 